\title{
UJI AKTIVITAS ANTI BAKTERI ASAP CAIR YANG BERASAL DARI BATANG KAYU MANIS DAN KULIT KACANG TANAH
}

\author{
Yefrida, Farrah Aprilina, Indri Ticel Leone, Refilda, Marniati Salim \\ Jurusan Kimia, FMIPA Unand
}

\begin{abstract}
ABSTRAK
Antibacterial agent is a compound that prevent the growth and reproduction of bacteria. Antibacterial activity of liquid smoke is caused by acid and fenolic compound. In this research, we determined antibacterial activity of liquid smoke from stem sweet wood and nut shell by using diffusion method. Both of liquid smoke have antibacterial activity to Staphylococcus aureus Eschericia coli population. Their activity almost the same to chloramphenicol, but less than formalin.
\end{abstract}

Keywords : antibacterial activity, liquid smoke, diffusion method

\section{DAFTAR PUSTAKA}

1. P. Darmaji, Aktivitas Antibakteri Asap Cair yang Diproduksi dari Bermacam-Macam Limbah Pertanian, Laporan Penelitian Mandiri, DPP-UGM, 1996, 16: 19-22.

2. P. Darmaji, Produksi Asap Cair dan Sifat-Sifat Antimikrobia, Antioksidan serta Sensorisnya, Laporan Penelitian Mandiri, DPP-UGM, 1996, 19; 11-15.

3. J. P. Girard, Smoking In: Technology of Meat and Meat Products, J. P Girard and I. Morton (ed) Ellis Horword Limited, New York, 1992.

4. http://www.tufts.edu/med/apua/print/Q\&A/Q\&A antibacterials.html\#3.

5. Y. K. Yefrida, R. Putri, N. Silvianti, Lucia, Refilda, Indrawati, Pembuatan asap cair dari limbah Kayu suren (Toona sureni), sabut kelapa dan tempurung kelapa (Cocos nucifera Linn), Jurnal Riset Kimia, 1(2), 187-191, (2008).

6. Y. K. Putri, Pemanfaatan Limbah Kayu Suren Sebagai bahan pembuatan Asap cair dan Karakterisasinya Menggunakan GC-MS, Skripsi Sarjana Kimia, Unand, 2006.

7. . Lucia, Pemanfaatan Limbah Tempurung Kelapa (cocos nucifera) Sebagai Bahan Pembuat Asap Cair dan Karakterisasinya Menggunakan GC-MS. Skripsi Sarjana Kimia, 2006, Unand.

8. H. A. Joly, N. Li, N. Belzie, Pyrolisis, Gas Chromatography-Mass Spectrometry of Humic Substances Extracted From Canadian Lake Sediments, Canadian Journal of Chemistry, 78(1): 51, (2000).

9. Yuharmen, Y. Eryanti, Nurbalatif, Uji Aktivitas Antimikroba Minyak atsiri dan Ekstrak Metanol Lengkuas (Alpinia galanga), UNRI, 2002.

10. S. Etrisna, Uji Aktivitas Antibakteri Katekin Daun Gambir Sirih Terhadap Vibrio Cholerae dan Vibrio Parahaemolyticus, Skripsi Sarjana Farmasi, UNAND.

11. L. B. Widiyati, Analisis Mikroba di Laboratorium, Jakarta, 1994.

12. A. J. John, V. P. Karunakaran, V. George, N. S. Pradeep, M. G. Sethuraman, Chemical Composition and Antibacterial Activity of Leaf Oil of Neolitsea Foliosa (Nees) Gamble Var, Caesia (Meisner) Gamble, Journal of Essential Oil, 19(5): 498, (2007).

13. B. Sabulal, R. Kurup, V. George, M. Dan, N. S. Pradeep, Chemical Composition and Antibacterial Activity of The Rhizome and Leaf Oils of Amomum Hypolencum Thwaites, Journal of Essential Oil Research, 19(3): 279, (2007). 
